\title{
Palaeoflood activity and climate change over the last 1400 years recorded by lake sediments in the NW European Alps
}

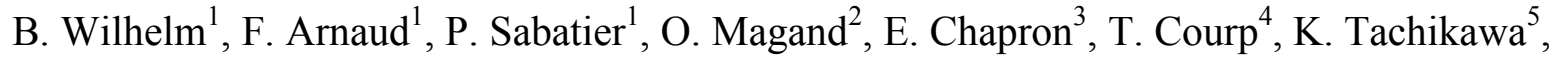 \\ B. Fanget ${ }^{1}$, E. Malet ${ }^{1}$, C. Pignol ${ }^{1}$, E. Bard ${ }^{5}$, J.J. Delannoy ${ }^{1}$
}

(1) EDYTEM, Université de Savoie, CNRS, Pôle Montagne, 73376 Le Bourget du Lac, France, fabien.arnaud@univ-savoie.fr, Pierre.Sabatier@univ-savoie.fr, Bernard.Fanget@univ-savoie.fr, emmanuel.malet@univ-savoie.fr, cecile.pignol@univsavoie.fr, Jean-Jacques.Delannoy@,univ-savoie.fr

(2) LGGE, Université Joseph Fourier, CNRS, 54, rue Molière, BP 9638402 Saint-Martin d'Hères cedex, France, Olivier.Magand@lgge.obs.ujf-grenoble.fr

(3) ISTO, Université d'Orléans, CNRS, BRGM, Observatoire des Sciences de l'Univers en région Centre, 1A rue de la Férollerie, 45071 Orléans Cedex 2, France

Emmanuel.Chapron@univ-orleans.fr

(4) CEFREM, Université de Perpignan via Domitia-CNRS, 52 Avenue Paul Alduy, 66860 Perpignan Cedex, France, thierry.courp@univ-perp.fr

(5) CEREGE, Université Aix-Marseille, CNRS, IRD, Collège de France, Technopole de 1’Arbois, BP 80, 13545 Aix en Provence, France, kazuyo@cerege.fr, bard@,cerege.fr

e-mail : bruno.wilhelm@,univ-savoie.fr 


\begin{abstract}
A high-resolution sedimentological and geochemical study of a high-altitude proglacial lake (Lake Blanc, Aiguilles Rouges, 2352m a.s.1.) revealed 195 turbidites, 190 of which are related to flood events over the last 1400 years. We used the coarsest sediment fraction of each turbidite as a proxy for the intensity of each flood event. Because most flood events at this locality are triggered by localized summer convective precipitation events, the reconstructed sedimentary record reveals changes in the frequency and intensity of such events over the last millennium. Comparisons with other temperature, paleohydrological and glacier reconstructions in the region suggest that the most intense events occurred during the warmest periods, that is, during the Medieval Climate Anomaly (AD 800-1300) and the current period of global warming. On a multi-decadal time scale, almost all the flood frequency peaks seem to correspond to warmer periods, whereas multi-centennial variations in flood frequency appear to follow the regional precipitation pattern. Consequently, this new Alpine flood record provides further evidence of a link between climate warming and an increase in the frequency and intensity of flooding on a multi-decadal time scale, whereas the centennial variability in flood frequencies is related to regional precipitation patterns.
\end{abstract}

Keywords: lake sediment, flood frequency, flood intensity, last millennium, climate change

\title{
1. Introduction
}

Extreme precipitation events can trigger floods that may have serious human and economic consequences (Gaume et al., 2009). Although theoretical studies and numerical simulations suggest that global warming will lead to an increase in the frequency and/or intensity of such events (IPCC, 2007), the relationship between flood events and climate change is difficult to assess because the lack of long-term meteorological data at high altitude sites (e.g. Beniston et $a l ., 2007)$ and the stochastic nature of extreme events preclude the identification of long-term trends. One way of overcoming this problem is to extend documentary records beyond observational data by reconstructing long-term geological archives of intense flood events. Such long-term records can than be used to build a better understanding of how local to regional flood hazard patterns are likely to be affected by global warming and thereby improve predictive models (IPCC, 2007 and references therein). 
Lake sediments are continuous archives in which it is possible to identify high-energy sediment layers and thus reconstruct mountain-river flood records (e.g. Arnaud et al., 2002; Gilli et al., 2003; Bøe et al., 2006; Moreno et al. 2008; Storen et al., 2010; Wilhelm et al., 2012a, 2012b). In addition, the relative intensities of paleo-floods can be assessed from the size of the coarsest sediment fraction in each flood layer, as sediment grain size depends on the stream flow velocity (Campbell, 1998; Parris et al., 2010). In some cases, the thickness of flood deposits can also be used as a proxy for flood-intensity (Nesje et al. 2001; Wilhelm et al., 2012a, 2012b).

Few studies in the European Alps have attempted to use lake sediment records to reconstruct both the frequency and intensity of extreme floods. The small amount of data available suggests that proglacial lakes (Stewart et al., 2011; Wilhelm et al., 2012a) are good candidates for this type of study, as they are less sensitive to the human-driven processes that often dominate climate-erosion-sedimentation interplays (Dapples et al., 2002; Giguet-Covex et al., 2011). A previous study has also reported a relationship between mountain-river flood activity and temperature, with increased flood frequency and intensity during warmer periods over the last 250 a (Wilhelm et al., 2012a). A major limitation on the use of proglacial lake sediments for studying flood activity is the presence of plant remains for radiocarbon dating. In this respect, Lake Blanc in the Aiguilles Rouges is an excellent locality for studying millennial-scale variations in flood frequency because its catchment area contains both a glacier, which delivers clastic material, and sparse vegetation. Consequently, we were able to extend our results beyond the period covered by Wilhelm et al. (2012a) and draw up a record of the frequency and intensity of extreme flood events over a time span covering both warm (Medieval Climate Anomaly) and cold (Little Ice Age) periods. By doing so we were able to test the hypothesis that flood frequency and intensity increase during warmer periods.

\section{Study area}

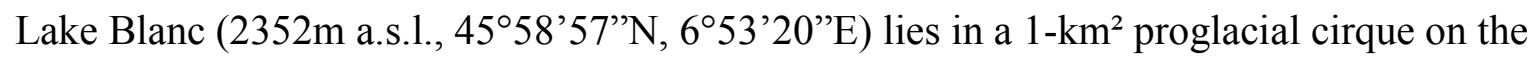
right bank of the River Arve, just north of the Mont-Blanc Range (Fig. 1). The catchment consists mainly of gneiss with a small lens of sedimentary rocks (quartzite and limestone) at the top of the highest peak, the Aiguille du Belvédère (2965m a.s.1.). Roches moutonnées and thick glacial deposits indicate substantial past erosion of the substratum by the Belvédère 
Glacier. Due to glacial retreat, the glacier now occupies only $4 \%$ of the catchment, whereas glacial deposits cover approximately $30 \%$ of the catchment. Given the absence of vegetation on the glacial deposits, this larger area probably corresponds to the maximum advance of the Belvédère Glacier during the Little Ice Age (LIA). Erosion of the glacier foreland and transport by a proglacial stream means the lake receives a continuous input of glacial material that has built a large delta at the mouth of the stream (Fig. 1 and 2) and ensures the lake waters remain turbid throughout the thaw period. From November to May, the catchment is covered by snow and the lake is frozen; therefore, nearly all sediment input occurs during the summer and early autumn. However, during the winter period lake sediments can be affected by avalanches, as shown by the exceptionally large avalanche that occurred during the winter of 1986. As well as destroying the upper floor of the old mountain hut (Fig. 1), this avalanche broke the lake's ice cover and ejected fine sediments from both Lake Blanc and a small lake located downstream (Lignier, 2001 and references therein).

The catchment area and the lake have very similar characteristics to another Lake Blanc, $100 \mathrm{~km}$ south of the Aiguilles Rouge, in the Belledonne Mountains (2170m a.s.1., 45¹0'42”N, 5'58'21'E). Although the Belledonne Lake Blanc catchment is slightly larger $\left(3 \mathrm{~km}^{2}\right)$ than the Aiguilles Rouge Lake Blanc catchment $\left(1 \mathrm{~km}^{2}\right)$, the two lakes have similar climates (KiefferWeisse and Bois, 2001), lie in steep-sided proglacial cirques consisting mainly of gneiss and have large proglacial areas as their sediment main source (Wilhelm et al., 2012a). These similarities suggest that the Aiguilles Rouges Lake Blanc is a suitable site for extending the flood record established for the Belledonne Lake Blanc.

\section{Material and methods}

\subsection{Seismic survey and coring}

The bathymetry of the lake and the geometry of its sedimentary infill were investigated in September 2008 by high-resolution seismic profiling using an INOMAR SES-2000 Compact system (mean frequency of $8 \mathrm{kHz}$ ) coupled with DGPS navigation. Sub-bottom profiling was carried out from an inflatable boat, following a perpendicular grid with $20 \mathrm{~m}$ spacing between each profile (Fig. 2). We used the resulting database to select coring sites in the main basin along a proximal-distal transect starting in the delta, where sedimentary infill is thickest and least affected by sub-aquatic mass-wasting processes. 
In the winters 2009 and 2010 we retrieved one short (BAR09P1; 45 58'58.7'N, 653'19.6'E) and two long (BAR10I; 4558'58.27'N, 653'20.53'E and BAR10II; 4558'57.66”N, $6^{\circ} 53$ '21.45”E) cores from the frozen surface of the lake using an UWITEC gravity corer for the short core and a piston corer for the long cores. Multiple cores were drilled in order to obtain a second assessment of the spatial extent of the lake basin deposits that could be combined with the seismic profiles. The BAR10I $(2.8 \mathrm{~m})$ and BAR10II $(2.5 \mathrm{~m})$ cores both stopped at a horizon made up of semi-angular decimetre-scale blocks in the middle of the lake sediment infill. Cores BAR10I and BAR10II are composed of three and four sections, respectively, plus a short gravity-core per site (BAR10P02 and BAR10P04, respectively) taken to provide well-preserved water-sediment interface samples. The deepest BAR10I section was lost and is therefore missing from the composite sequence. We constructed composite sequences, using the thick and distinctive graded beds that appear in each section to ensure a precise and reliable stratigraphic correlation.

\subsection{Core description and logging}

Cores were split lengthwise and photographed at high resolution (20 pixels $/ \mathrm{mm})$. We examined the visual macroscopic features of each core in detail in order to determine the different sedimentary facies, which we then used to determine the stratigraphic correlation between the cores. We calibrated the seismic data using physical measurements (P-wave velocity and gamma-ray attenuation bulk density) carried out on the GeotekTM multisensor core-logger at the Chrono-Environnement Laboratory. Grain size measurements were carried out on core BAR10II (Malvern Mastersizer 2000) at a 5mm continuous sampling interval. Interbedded deposits were characterized on the basis of their median (Q50) and coarse (Q90) fractions (Passega, 1964; Shiki et al., 2000; Mulder et al., 2001). We also recorded the thickness and Q90max (i.e., highest Q90 value) of each interbedded deposit as a proxy for the quantity and the grain size of sediment mobilized and, therefore, water-current energy (Campbell 1998, Parris et al., 2010). Geochemical element analysis was carried out using Xray fluorescence (XRF) core scanner Itrax ${ }^{\mathrm{TM}}$ (Cox Analytical System) at the CEREGE laboratory, using a Chromium tube (35 keV, $40 \mathrm{~mA})$, a $15 \mathrm{~s}$ count-time and a $1 \mathrm{~mm}$-sampling step. The areas of the element peaks provide an indication of the relative concentrations of each element (Tachikawa et al., 2011). Among the measured elements, Iron (Fe), Calcium (Ca) and Zirconium $(\mathrm{Zr})$ were investigated as high-resolution grain-size proxies for identifying the thinnest interbedded deposits (Cuven et al., 2010, Giguet-Covex et al., 2011; 
Wilhelm et al., 2012a) and to help constrain the stratigraphic correlation between the three cores. Given the geology of the catchment area, Fe is probably associated with clays, Ca with feldspars in the gneiss or carbonates in the limestone, and $\mathrm{Zr}$ to zircons in the sediment (Lignier, 2001).

\subsection{Dating methods}

${ }^{137}$ Caesium (Cs) measurements on the upper $70 \mathrm{~cm}$ of core BAR09P1 were carried out at the LGGE (Grenoble). Measurement intervals followed facies boundaries, resulting in a nonregular sampling step of approximately one centimeter. The thick bed between 6 and $24 \mathrm{~cm}$, which we considered an instantaneous deposit, was not analyzed. ${ }^{137} \mathrm{Cs}$ was introduced into the environment by atmospheric nuclear weapon tests (AD 1958-1963) and the Chernobyl accident (AD 1986; Radakovitch et al., 1999); therefore, the appearance of ${ }^{137} \mathrm{Cs}$ in the sedimentary record is a reliable chronostratigraphic marker for the end of the 1950s. In addition, the bases of the flood deposits contained small vegetal macro-remains, some of which were large enough to be identified as pine needles and herbaceous stems. We sent nine samples to the LMC14 national carbon measurement laboratory for AMS ${ }^{14} \mathrm{C}$ analysis. Because vegetal remains were absent from the deepest part of the sediment record, we also analyzed bulk sediment in order to test the reliability of bulk-sample ages. We did this by carrying out ${ }^{14} \mathrm{C}$ analyses on organic matter from a bulk sediment sample and on vegetalremains from the same sediment layer. ${ }^{14} \mathrm{C}$ ages were calibrated using the Intcal09 calibration curve (Reimer et al., 2009) (Table 1). The ${ }^{14} \mathrm{C}$ age for the bulk-sediment sample was twice as old as the ${ }^{14} \mathrm{C}$ age for the vegetal remains from the same layer. This may be due to the presence of fossil carbon from the sedimentary rocks or older carbon from the erosion of soils. Most importantly, this finding meant that we were unable to obtain a reliable age for the deepest part of the sediment record. We applied the R-code package "clam" (Blaauw, 2010) to generate an age model for the most distal core (BAR10II). We then used the stratigraphic correlation (Fig. 3) to recalculate the depths of all the ${ }^{14} \mathrm{C}$ samples for this core (Table 1). The most distal core was used for this purpose in order to minimize the effects on the sequence of erosion by high-energy sediment events.

\section{Results}

4.1. Lake morphology and sediment infill 
The seismic signal easily penetrated the regularly stratified lacustrine sediments in the main basin but became scattered and absorbed at the acoustic basement and at the NE end of the basin, where a steep delta has developed (Fig. 2). P-wave velocity measurements on sediment cores indicate that a mean velocity of $2000 \mathrm{~m} / \mathrm{s}$ should be used to estimate the thickness of the basin fill. Figure 2 shows that the progradation of the delta into the lake has resulted in the development of steep foreset beds (with very limited acoustic penetration) and well-stratified bottomset beds in the deeper basin. These bottomset beds are up to $5 \mathrm{~m}$ thick close to the delta but they quickly thin towards the lake outlet. The profile for the main basin showed several high-amplitude, sub-parallel reflections (labeled R1 to R4). Close to the lake floor, we identified a transparent to chaotic lens-shaped body that is thickest at the foot of the prodelta but extends over most of the main basin. The body's acoustic signature and form are typical of sub-aqueous mass-wasting deposits in clastic lakes with steep slopes (Chapron et al., 1999; 2007; Schnellmann et al. 2006; Fanetti et al, 2008).

\subsection{Lithostratigraphical description}

The sediment mainly consists of finely laminated silty-clay sediments interbedded with a coarse-grained layer, three deformed layers and 195 millimeter-to-centimeter thick normally graded beds.

\subsubsection{Coarse-grained layer}

A $1 \mathrm{~cm}$-thick coarse-grained layer is present at $158 \mathrm{~cm}$ in core BAR10II only. This layer consists mainly of coarse sand and small angular gravel in a silty-clay matrix (Fig. 3 and 4). These characteristics are highlighted by the layer's isolated position in the Passega-type diagram, with a very high $\mathrm{Q}_{90}$ value for a low $\mathrm{Q}_{50}$ value (Fig. 5).

\subsubsection{Deformed layers}

Some layers are characterized by a deformed structure and folded laminations. The uppermost of these layers occurs at $22-37 \mathrm{~cm}$ in the most proximal core (BAR09P1) and is overlain by a $16 \mathrm{~cm}$-thick normally graded bed (Fig. 3). BAR10II, which was taken at the foot of the western steep slope, contains a second deformed layer at $55-61 \mathrm{~cm}$. This layer is overlain by a 
thin normally graded bed. The third and deepest deformed layer occurs at $258-260 \mathrm{~cm}$ in BAR10I and corresponds to a flattened fold that duplicates a multi-millimeter-thick bed. This deformed layer is overlain by two $4 \mathrm{~cm}$-thick graded beds that are identical to the two beds below the deformed layer.

\subsubsection{Graded beds}

The graded beds are characterized by their higher density, sharp, coarse-grained and occasionally erosive base, and a fining-upward trend, indicated by the synchronous decrease of $\mathrm{Q}_{50}$ and $\mathrm{Q}_{90}$ (Fig. 5). Core BAR10II contained only one clear erosive contact, at the base of the thickest graded bed, at a depth of around $18 \mathrm{~cm}$. According to the stratigraphic correlation, all the graded beds but one extend over the entire lake basin (Fig. 3). The exception is a graded bed that occurs at approximately $60 \mathrm{~cm}$ in BAR09P1 and at $50 \mathrm{~cm}$ in BAR10I, indicating that this layer is restricted to the deepest part of the lake basin. Furthermore, when plotted on a thickness vs. Q90max graph, the BAR10II graded beds form two distinct clusters (Fig. 5). The left-hand cluster includes most of the graded beds and is characterized by a significant thickness- $\mathrm{Q}_{90 \max }$ relationship $(\mathrm{r}=0.79, \mathrm{p}<0.0001)$. The right-hand cluster consists of the four thickest beds. We interpreted the graded beds in the left-hand cluster as flood-induced turbidites, hence they are labeled FIT in figure 5 (see §5.1.3). We interpreted the graded beds in the right-hand cluster as slide-induced turbidites, hence they are labeled SIT in figures 3 and 5 (see $§ 5.1 .2$.). There is a good correspondence between the depths of the high-amplitude seismic reflections and three of the SITs, with R1 corresponding to SIT2, R2 corresponding to SIT4 and R3 corresponding to SIT5 (Fig. 2 and 3).

\subsection{High-resolution element geochemistry}

\subsubsection{Calcium contents}

Relative Ca contents vary little with depth, with just two well-marked peaks in the upper part of the sediment sequence (at approximately $39 \mathrm{~cm}$ and $42 \mathrm{~cm}$ in BAR10II). Although the absence of significant variations in the Ca contents of the graded beds precludes the use of this element as a grain-size proxy, the two peaks in the upper part of the sequence provide additional stratigraphic markers for correlations between the cores (Fig. 3). 
A plot of relative Fe contents vs. sediment depth (Fig. 4) showed increased Fe contents for the top parts of the millimeter-to-centimeter graded beds, suggesting Fe enrichment in the finest sediment fraction (Cuven et al., 2010; Wilhelm et al., 2012a). Potassium (K), which is mainly contained in the clay fraction, and $\mathrm{Fe}$ are covariant $(\mathrm{r}=0.85, p<0.0001)$, indicating that changes in Fe content are mainly related to grain size, rather than to oxydation-reduction processes. This conclusion is supported by the concordance between Fe content and the $<4 \mu \mathrm{m}$ grain size fraction (Fig. 4). Variations in $\mathrm{Zr}$ contents show the opposite pattern to changes in Fe content ( $\mathrm{r}=-0.79, p<0.0001$, between $\mathrm{Zr}$ and $\mathrm{Fe}$ ), with $\mathrm{Zr}$ enrichment in the basal part of the graded beds and thus in the Q90 fraction (Fig. 4). We found a significant correlation ( $\mathrm{r}=0.93$, $p<0.0001$ ) between the $5 \mathrm{~mm}$-resampled $\mathrm{Zr} / \mathrm{Fe}$ ratio and the $\mathrm{Q} 90 /[<4 \mu \mathrm{m}$ fraction] (Fig. 4), indicating that the $\mathrm{Zr} / \mathrm{Fe}$ ratio can be used as a high-resolution proxy for relative grain-size distribution and hence for detecting millimeter-scale graded beds.

\subsection{Dating results}

${ }^{137} \mathrm{Cs}$ was found to be present down to the base of the deformed layer at $38 \mathrm{~cm}$ in core BAR09P1 (MWD1, Fig. 3). ${ }^{137}$ Cs activity below this layer is null, showing that the material in the deformed layer was deposited after AD 1958.

We first constructed a composite sedimentary sequence by excluding all the interbedded deposits (Arnaud et al., 2002; Moreno et al., 2008; Giguet-Covex et al., 2011), which we interpreted as instantaneous deposits formed by rapid sedimentary processes (see $§ 5.1$ ). We then calculated a depth-to-age model by linear interpolation, using the "clam" R-code package (Blaauw, 2010). Although the results show that the sequence covers the last two millennia, because of the absence of ${ }^{14} \mathrm{C}$ ages for the deepest part of the sediment record, the following discussion only considers the upper $190 \mathrm{~cm}$ of BAR10II (i.e., the upper $85 \mathrm{~cm}$ of the composite sedimentary record, Fig. 6), which covers the last 1400 years.

\section{Discussion}

5.1. Different origins for the interbedded deposits

5.1.1. Avalanche origin 
The local presence of coarse sand and gravel in the unsorted coarse layer at $158 \mathrm{~cm}$ in core BAR10II (Fig. 3) suggests that this layer consists of material deposited by melting ice following a dirty avalanche (Seierstad et al., 2002; Chapron et al., 2007; Guyard et al., 2007; Vasskog et al., 2011).

\subsubsection{Mass movement origin}

The preservation of laminae below and above the deformed layers precludes a coring origin for the deformed sediments. Naturally deformed sediment layers are usually described as mass-wasting deposits (MWD), formed when sediments slide down a slope to form different kinds of mass flow or turbidite (e.g. Shiki et al., 2000; Monecke et al., 2004; Schnellmann et al., 2005; Chapron et al., 1999; 2007; Girardclos et al., 2007; Bertrand et al., 2008; Fanetti et $a l ., 2008)$. Support for such a mass flow origin is provided by the good match between the depth and location of the thick deformed layer in BAR09P1 (MWD1, Fig. 3) and the MWD revealed by the seismic data (Fig. 2). However, the MWD2 deformed layer does not correspond to a seismic-detected event. This may be because the thickness of the layer $(8 \mathrm{~cm})$ is below the vertical resolution of the seismic data (approx. 20cm) or because it is composed of less dense sediment than MWD1, which is at the foot of the delta. In addition, the duplicated sediment sequence separated by the folded layer in BAR10I can only be explained by a slide from the delta slope to the deepest part of the lake basin. Consequently, we also interpreted the folded layer and the two overlying beds as a mass wasting deposit (MWD3, Fig. 3). Seismic data suggests that the thick graded bed (indicated by SIT5, Fig. 3) just below MWD3 may correspond to high-amplitude reflection R3 (Fig. 2).

On the other hand, graded beds are common features in lake sediments, where they are associated with turbidity currents triggered by either flood events or mass movements (e.g. Sturm and Matter, 1978; Shiki et al., 2000; Arnaud et al., 2002; Gilbert et al., 2006; Mulder and Chapron, 2011; Wilhelm et al., 2012a). In the latter case, they are formed by the sediment that is transported in suspension during the mass movement and then deposited over the mass wasting deposit and/or further in the lake basin (e.g. Shiki et al., 2000; Schnellmann et al., 2005; Girardclos et al., 2007; Fanetti et al., 2008). Consequently, such graded beds are generally confined to a restricted area of the lake basin and often contain larger quantities of sediment than graded beds produced by flood events (e.g. Shiki et al., 2000; Schnellmann et al., 2005; Fanetti et al., 2008; Wilhelm et al., 2012a). The only well-marked graded bed is 
restricted to the deepest part of the lake basin (indicated by SIT3, Fig. 3), suggesting that it corresponds to a slide-induced turbidite (SIT). Furthermore, the thick graded bed indicated by SIT1 in figure 3 directly overlies MWD1 and was, therefore, almost certainly produced by the deposition of sediment suspended in the water column during the mass movement that produced MWD1. The isolated position of SIT1 in the thickness-Q90max $\operatorname{diagram~(Fig.~5B)~}$ also supports a SIT interpretation, with this bed representing a rare case in which a large quantity of sediment was transported without an exceptionally high current energy. Thus, MWD1 and SIT1 were probably produced by the same mass movement. The right-hand cluster in the $\mathrm{Q}_{90}$-thickness diagram contains three other thick graded beds with similar characteristics to SIT1 (Fig. 5B), suggesting a mass movement origin for all these beds. Therefore, they are also interpreted as SIT deposits (SIT2, SIT4 and SIT5, Fig. 3).

\subsubsection{Flood origin}

All the other graded beds, which extend over the entire basin, are grouped in a distinct cluster in the thickness- $Q_{90 \max }$ diagram and are therefore likely to have been formed in the same way (Fig. 5B). A flood origin for these beds is supported by the presence of terrestrial vegetal remains within the beds and their frequent occurrence (mean recurrence time of $7 \mathrm{a}$ ). In addition, the linear thickness- $Q_{90 \max }$ relationship is consistent with sedimentary processes regulated by water currents, with higher discharge rates leading to greater sediment supply and coarser material. Consequently, we interpret all the 190 graded beds thinner than $4 \mathrm{~cm}$ as flood-induced turbidites (FIT). The significant relationship $(\mathrm{r}=0.79, p<0.0001)$ between the flood deposit thickness and the $\mathrm{Q}_{90 \max }$ values also suggests that the $\mathrm{Q}_{90 \max }$ can be indirectly assessed through the deposit thickness.

\subsection{Chronological controls on mass-movement related deposits}

The ages of the most recent MWD and SIT can be compared with the dates of historic events capable of creating mass movements consistent with the characteristics of the sediments. Mass movements may be the result of spontaneous mass failures caused by sediment overloading, snow avalanches, local seismic activity or variations in lake-level (Monecke et al. 2004). In the present case, this latter possibility is unlikely to have played a role because the lake outlet is made of bedrock. 
The presence of ${ }^{137} \mathrm{Cs}$ in MWD1 indicates that this deposit and the overlying SIT1 (Fig. 3) are more recent than AD 1958, whereas the age-depth model yielded an age of AD 1949 (Fig. 6). The difference between the two ages may result from ${ }^{14} \mathrm{C}$ uncertainties and/or from a sedimentary hiatus, as suggested by the erosive base of SIT1. No high-magnitude earthquakes have occurred in the region in recent decades; however, in AD 1986 an exceptionally large avalanche, originating in the upper part of the catchment, swept away the old mountain hut, which was built on the rock sill damming the lake (Fig. 1) According to local witnesses, just after the avalanche, the rocky lake outlet was covered in sediment (Lignier, 2001 and references therein). This observation supports the hypothesis that the avalanche-triggered event led to significant erosion of the lake bottom and produced the MWD1 and SIT1 deposits. The difference between this historic date and the most probable age of AD 1949 for these deposits suggests thus a hiatus of about 30-40 a under SIT1.

The most probable age for SIT2 is AD 1903, which is consistent with the Emosson and MontBlanc earthquakes, which occurred approximately 10km from the lake in April and August 1905 and which had magnitudes of 5.5 and 5.2, respectively (Lambert and Levret-Albaret, 1996; Fig. 1 and 6). Previous research has correlated these earthquakes with mass movements in Lake Anterne, only $7 \mathrm{~km}$ from Lake Blanc (Arnaud et al., 2002). In addition, SIT2 consists of two sub-units, with $\mathrm{Zr} / \mathrm{Fe}$ ratios indicating the presence of coarse material at the base and in the middle of the deposit (Fig. 3). Each sub-unit is probably the result of one of the two 1905 earthquakes.

The most probable age for SIT3 is AD 1813, which concords with the magnitude-4.8 Chamonix earthquake that occurred in AD 1817 (Lambert and Levret-Albaret, 1996; Fig. 1 and 6). This event has also been correlated with a mass movement in Lake Anterne (Arnaud et al., 2002).

Finally, age probabilities for MWD2 show two peaks, in AD 1595 and 1519. No earthquakes are known to have occurred close to the lake during this period. However, two highmagnitude earthquakes occurred less than 50km away, in $\mathrm{AD} 1584(\mathrm{Mw}=5.9)$ on the southeastern shore of Lake Geneva, and in AD $1524(\mathrm{Mw}=5.8)$ close to Sion (Swiss seismologic service database: http://www.seismo.ethz.ch/). Given the correspondence between the most probable age for MWD2 (AD 1595) and the age of the highest magnitude earthquake (AD1584), it seems probable that MWD2 was the result of the AD 1584 earthquake. However, other synchronous mass movements in the region need to be identified in order to confirm this correlation. SIT4 was dated at AD 1429. Due to the absence of reliable historic information, we did not investigate possible correlations. Overall, there is good agreement 
between major historic events and the calculated ages of the slide-induced deposits, supporting their interpretation as mass-movement deposits and our chronology, at least over the last six centuries.

\subsection{Paleoflood record}

By dating the 190 FITs we were able to build up a flood record for the lake, from which we calculated a 31-year running total in order to highlight changes in flood frequency (Fig. 7). We determined periods during the last millennium in which the most intense events occurred by including in the flood record the thickness of each FIT as a proxy for flood intensity because thickness and $Q_{90 \max }$ values are well correlated (Wilhelm et al., 2012b). The FITs are characterized by high $\mathrm{Q}_{90 \max }$ values, which reflect high-energy sediment inputs (Fig. 5B). According to monitoring data acquired in the neighboring Lake Anterne over a 5 a period, at the difference of rainstorms, seasonal snowmelt in high altitude catchment areas never generates water current with a sufficient capacity to transport sandy particles (Enters et al., 2010). More information on the triggering mechanisms of high altitude torrential floods is provided by the study of the Belledonne Lake Blanc (Wilhelm et al., 2012a). In that case it was possible to compare the flood calendar established from lake sediments with historical flood dates over the last 250 a. It appeared that all historical floods reported in local archives were identified in lake sediments and corresponded to the coarsest grained and thickest ones. Moreover, almost all these events corresponded to rainstorm that occurred between July and September. We hence assume that FITs were most probably formed by rainstorms generating high-magnitude river runoff events that eroded and transported moraine material from the glacier foreland, spreading it over the whole lake basin (Blass et al., 2003; Stewart et al., 2011; Wilhelm et al., 2012a). As a consequence, both internal - the availability in erodible sediment - and external - the intensity and recurrence-time of rainstorms - must be considered when trying to exploit our flood calendar to inform past climate variability.

5.3.1. Environmental changes, glacier dynamics and the availability in erodible material

Lake Blanc is currently located well-above the timberline and is virtually free of any high stand vegetation. Even alpine grasslands are sparse, probably explaining why local populations never exploited it for grazing activities. As a consequence, over the considered 
period, no changes in local environment are susceptible to have affected the climate-erosion relationship. This is not true for geomorphological changes due glacier dynamics. Indeed, the main sediment source in the Lake Blanc catchment is the moraine material that covers $30 \%$ of the catchment area. This fresh glacier material was accumulated during Neoglacial glacier advances (Holzhauser et al., 2005; Ivy-Ochs et al., 2009) and was therefore present throughout the studied period. However, substantial glacier advances/retreats can modify sediment availability in proglacial catchments (Hodder et al., 2007; Larsen et al., 2012). Varve-based reconstructions of annual sediment yields in proglacial environments have been used to describe and discuss these complex processes (e.g. Hodder et al., 2007 and references therein), but very few studies have examined the relationship between changes in glacier length and erosion processes in glacier forelands during flood events. In theory, the progressive disappearance of ice cover during substantial glacier retreats will release moraine material, resulting in a greater amount of mobilized material for a given flood event intensity. Conversely, through a shielding effect, a greater extension of the ice cover could increase the necessary threshold for the erosion of moraine material and the resulting flood deposit formation, and could thus decrease the flood frequency. Both of these processes could bias the reconstructed flood signal in terms of intensity and frequency, respectively. The conservation throughout the considered period of the grain-size $v s$. thickness relationship suggests that the relation between the intensity of flood events and the volume of transported material remained constant (Fig. 4). However, to further test the hypothesis of a link between glacial advance/retreat and flood frequency/intensity, we compared the Lake Blanc flood record with the high-resolution, continuous reconstructions of glacial fluctuations for the Bossons and Aletsch Glaciers (Holzhauser et al., 2005; Nussbaumer and Zumbühl, 2012; Fig. 7). The Bossons Glacier is well suited for comparison with the Belvedère Glacier as the two glaciers are only a few kilometers apart (Fig. 1) and are characterized by short response times to climatic changes (Kuhn et al., 1985; Nussbaumer and Zumbühl, 2012). Therefore, fluctuations in the Belvedère Glacier, for which no reconstruction is available, are likely to have followed a similar pattern to the fluctuations revealed by the Bossons Glacier record. However, because the Bossons Glacier record is shorter than our study period, we needed another record that would provide an indication of glacial fluctuations for the older part of the Belvedère Glacier flood record. Despite its much greater size and correspondingly longer response times, the Aletsch Glacier reconstruction appeared to be the most suitable record for this purpose. The resulting comparison showed that the highest flood frequencies at Lake Blanc occurred close to periods of maximum glacial advance (e.g., ca. AD 1300-1400 and 
1750-1900), when, in theory, erosion processes should be more limited. In addition, some of the lowest flood frequencies occurred during periods of glacial retreat (e.g., ca.AD 800-950, AD 1150-1300), when erosion processes would be expected to be more efficient. These observations suggest that changes in glacier size do not seem to affect significantly the erosion processes in play during flood events. Erosion during glacier advances may be made possible due to the erosion of basal till by high-magnitude subglacial runoff events, which previous field observations have shown to be possible whatever the size of the glacier (Benn and Evans, 1998; Davies et al., 2003). Hence, climate is likely to be the dominant factor affecting the reconstructed flood signal.

\subsubsection{Type and timing of paleofloods in the regional climatic setting}

Floods occurring in the high-elevation areas of the northern flank of the European Alps are mainly triggered by summer convective events as shown over the last decades by instrumental data (Collins, 1998; Kieffer-Weisse and Bois, 2001; Merz and Blöschl, 2003) and over the last two centuries by historic data (Wilhelm et al., 2012a). In addition, the study of the Belledonne Lake Blanc suggested that flood layers were mainly triggered by summer convective events based on the comparison between ages of the flood layers and historic floods precisely dated (Wilhelm et al., 2012a). Due to the very similar characteristics of the catchments and lakes, the paleoflood record of the Aiguilles Rouges Lake Blanc is thereby interpreted as the recurrence of flood events mostly resulting from summer convective events. To discuss the evolution of the millennium-long flood frequency and intensity, the paleoflood record of Aiguilles Rouges Lake Blanc is then compared to temperature and precipitation data. Tree-ring studies and multi-proxy reconstructions have shown that the MCA (AD 8001300) was characterized by high summer temperatures (Büntgen et al., 2011; Trachsel et al., 2012). In addition, records of lake levels in the Jura region (Magny et al., 2004; 2011) and flood activity in the nearby River Rhone (Arnaud et al., 2012) show that the climate was mostly rather dry, with a short period of wetter conditions around AD 1050 (Magny et al., 2011, Fig. 7). The Lake Blanc flood record is consistent with this general pattern, as it includes a well-marked period of increased flood activity around AD 1050 that is associated with the thickest flood deposits, which we interpret as indicating high flood intensity. A progressive shift toward colder and wetter conditions at $c a$. AD 1300 marked the onset of the LIA (Millet et al., 2009; Büntgen et al., 2011; Magny et al., 2011, Trachsel et al., 2012; Fig. 7). At this time, River Rhone flood activity was at its highest level during the last millennium 
(Arnaud et al., 2012), as was the frequency of flooding in Lake Blanc, which also recorded a progressive decrease in sediment deposit thickness. The second part of the LIA (after $c a$. AD 1700) was characterized by the coldest temperatures, intermediate wetness conditions and a slight decrease in River Rhone flood activity. The Lake Blanc record also shows a decrease in flood frequency. In summary, comparing the LIA- and MCA-periods shows that the most intense events occurred during the warmest period but the highest flood frequency occurred during the colder and the wettest period. The flood frequencies revealed by the Lake Blanc sediment record are in agreement with regional wetness and hydrological conditions on a multi-centennial scale, suggesting that wetness levels play a key role in mountain-river flood activity on this time-scale.

In addition to this multi-centennial trend, the Lake Blanc flood record contains a multidecennial signal. The signal for the last three centuries can be compared with a recently established flood reconstruction for another Lake Blanc, in the Belledonne Mountains, approximately 100km SW of the Aiguilles Rouges Lake Blanc (Wilhelm et al., 2012a). The two records show very similar periods of higher flood frequency (AD 1780-1810, 1840-1880 and 1910-1960, Fig. 7), and these periods of high flood frequency are also the periods when the most intense flood events occurred. However, there is no clear relationship between these periods and the summer precipitation record for the European Alps (Casty et al., 2005). The absence of similarities may be due to the different processes recorded by each record: punctual intense precipitation events $v s$. mean seasonal precipitation. This suggests, however, that the seasonal precipitation level may not influence the flood frequency or intensity on a multi-decennial time-scale. This contrasts with the pattern seen over a multi-centennial timescale. In terms of temperature variations, periods of higher flood frequencies correspond well with warmer periods, as previous research has suggested (Wilhelm et al., 2012a). The good agreement between temperature peaks and the highest flood frequencies and intensities at the Lake Blanc Aiguilles Rouges suggests the presence of such a relationship throughout the last millennium. The only anomaly occurred $c a$. AD 1600-1770, which was a period of very cold temperatures in the European Alps (Trachsel et al., 2012). The cause for this may have been internal (e.g., longer periods of lake ice-cover or the temporary presence of permafrost in the proglacial foreland, which might have limited erosion processes) or external (e.g., a major change in the meteorological phenomena triggering flood events in the area). Permafrost cannot be absolutely excluded at this altitude, although there is no evidence that ice is currently present in any part of the proglacial foreland (as observed for instance by Stoffel et 
al., 2005) and studies suggest that permafrost only occurs at higher altitudes at sites with a south-easterly aspect (Haeberli, 1975). Furthermore, flood events in small, high-altitude catchment areas in the northern flank of the European Alps are mostly produced by intense precipitation triggered by localized summer convective events (Collins, 1998; Kieffer-Weisse and Bois, 2001; Merz and Blöschl, 2003). Cold temperatures are likely to weaken convective conditions, resulting in a decrease in the intensity of precipitation events and hence reducing flood activity during colder parts of the LIA.

On the other hand, comparisons with the high-resolution reconstruction of River Rhône flood activity do not show a consistent relationship at this time scale. This may be due to differences in the meteorological processes that generate flooding in large rivers and in small mountain catchments. In fact, most floods in large rivers, such as the Rhône, are triggered by long precipitation events associated with synoptic or frontal type storms ("long-rain type floods", Merz and Blöschl, 2003).

Consequently, our results suggest that the occurrence of summer convective events triggering mountain-river floods may be influenced by both average wetness on a multi-centennial scale and temperature on a multi-decennial scale. In addition, the intensity of flood events seems to increase with increasing temperature on all time scales. This suggests that higher temperatures lead to more efficient convection, thereby producing very heavy local rainfall events and, in turn, high-intensity flood events. This long-term proxy-based observation is consistent with theory (e.g. Trenberth, 1999), direct observations (e.g. Beniston et al., 1997) and simulations (Schär et al., 1996; Christensen and Christensen, 2004; Beniston et al., 2007).

\section{Conclusion}

Detailed sedimentological and geochemical analysis of a proximal-distal core transect allowed us to identify 195 turbidites. We interpreted the five thickest turbidites as the products of gravity processes because of the exceptionally high quantities of material transported and the position of the most recent turbidite directly above a slump. The concordance between the ages of these deposits and the dates of local major earthquakes support this interpretation and the chronology. For the remaining 190 turbidites, we found a strong relationship between deposit thickness and coarse fraction content (Q90 $\max$ ), suggesting that these turbidites were produced by floods and that deposit thickness can be used as a highresolution proxy for paleoflood intensity. 
As there is no evidence for any major glacier-related changes in erosion processes in the catchment, we interpret the Aiguilles Rouges Lake Blanc record as reflecting repeated intense summer precipitation events over the last 1400 years. Consequently, our study provides new evidence that warming may play an important role in flood activity, favoring an increase in flood intensity and flood frequency on a multi-decennial time scale. In addition, general wetness appears to be an important trigger mechanism that increases flood frequencies on a multi-centennial time-scale. Hence, our study suggests that past extreme flood events are the result of complex, time-scale-dependent interplays between the movement of air masses which bring moisture to landmasses - and landmass meteorological conditions, which influence the stability of humid air masses. The complex relief of areas such as the European Alps further complicates these interplays. Predictions of the consequences of the current episode of global warming must take into account this complexity.

\section{Acknowledgments}

B. Wilhelm's PhD research was partly funded by a grant from the Assemblée des Pays de Savoie and the Communauté de Communes du Grésivaudan. Logistical and financial support was provided by the French National Research Agency's Pygmalion project (ANR BLAN072_204489). Radiocarbon dating was performed by the national facility LMC14 in the framework of the INSU ARTEMIS call-for- proposal. The authors would also like to thank Claire Delhon (CEPAM) for her help in identifying vegetal remains, Jean-Pascal Dumoulin (LMC14) for his careful processing of our samples for radiocarbon dating, Marta Garcia for her excellent technical advice on using core scanners, Laurent Perdereau (ISTO) for his contribution to DGPS measurements during the seismic survey, Jean-Charles Sage for looking after us at the Lake Blanc mountain hut during the surveys, all the people who contributed to the coring surveys and the two anonymous reviewers for their helpful and constructive comments.

\section{References}

Arnaud F, Lignier V, Revel, M, Desmet M, Pourchet M, Beck C, Charlet F, Trentesaux A, Tribovillard N. 2002. Flood and earthquake disturbance of 210Pb geochronology (Lake Anterne, North French Alps). Terra Nova 14 : 225-232. 
Arnaud F, Révillon S, Debret M, Revel M, Chapron E, Jacob J, Giguet-Covex C, Poulenard J, Magny M. 2012. Lake Bourget regional erosion patterns reconstruction reveals Holocene NW European Alps soil evolution and paleohydrology. Quaternary Science Reviews 51 : 8192

Beniston M, Stephenson DB, Christensen OB, Ferro CAT, Frei C, Goyette S, Halsnaes K, Holt T, Jylhä K, Koffi B, Palutlikof J, Schöll R, Semmler T, Woth K. 2007. Future extreme events in European climate: an exploration of regional climate model projections. Climatic Change 81 : 71-95.

Benn DI, Evans DJA. 1998. Glaciers and Glaciations. Edward Arnold, London.734 pp.

Bertrand S, Charlet F, Chapron E, Fagel N, De Batist M. 2008. Reconstruction of the Holocene seismotectonic activity of the Southern Andes from seismites recorded in Lago Icalma, Chile, $39^{\circ}$ S. Palaeogeography, Palaeoclimatology, Palaeoecology 259 : 301-322.

Blaauw M. 2010. Methods and code for 'classical' age-modelling of radiocarbon sequences. Quaternary Geochronology 5: 512-518.

Blass A, Anselmetti FS, Ariztegui D. 2003. 60 years of glaciolacustrine sedimentation in Steinsee (Sustenpass, Switzerland) compared with historic events and instrumental meteorological data. Eclogae Geologica Helvetia 96(1) : 59-71.

Bøe AG, Olaf Dahl S, Lie O, Nesje A. 2006. Holocene river floods in the upper Glomma catchment, southern Norway: a high-resolution multiproxy record from lacustrine sediments. The Holocene 16(3) : 445-455.

Büntgen U, Tegel W, Nicolussi K, McCormick M, Frank D, Trouet V, Kaplan JO, Herzig F, Heussner KU, Wanner H, Luterbacher J, Esper J. 2011. 2500 Years of European Climate Variability and Human Susceptibility. Science 331(6017) : 578-582.

Campbell C. 1998. Late Holocene Lake Sedimentology and Climate Change in Southern Alberta, Canada. Quaternary Research 49 : 96-101. 
Casty C, Wanner H, Luterbacher J, Esper J, Böhm R. 2005. Temperature and precipitation variability in the European Alps since 1500. International Journal of Climatology 25:18551880.

Chapron E, Beck C, Pourchet M, Deconinck JF. 1999. 1822 earthquake-triggered homogenite in Lake Le Bourget (NW Alps). Terra Nova 11 : 86-92.

Chapron E, Faïn X, Magand O, Charlet L, Debret M, Mélières MA. 2007. Reconstructing recent environmental changes from proglacial lake sediments in the Western Alps (Lake Blanc Huez, 2543m a.s.1., Grandes Rousses Massif, France). Palaeogeography, Palaeoclimatology, Palaeoecology 252 : 586-600.

Christensen OB, Christensen JH. 2004. Intensification of extreme European summer precipitation in a warmer climate. Global and Planetary Change 44 : 107- 117.

Collins D. 1998. Rainfall-induced high-magnitude runoff events in highly-glacierized Alpine basins. Hydrology, Water Resources and Ecology in Headwaters. IAHS Publications. 248 : 69-78.

Corona C, Guiot J, Edouard JL, Chalié F, Büntgen U, Nola P, Urbinati C. 2010. Millenniumlong summer temperature variations in the European Alps as reconstructed from tree rings. Climate of the Past 6 : 379-400.

Cuven S, Francus P, Lamoureux S. 2010. Estimation of grain size variability with micro Xray fluorescence in laminated lacustrine sediments, Cape Bounty, Canadian High Arctic. Journal of Paleolimnology 44(3) : 803-817.

Dapples F, Lotter AF, van Leeuwen JFN, van der Knapp WO, Dimitriadis S, Oswald D. 2002. Paleolimnological evidence for increased landslide activity due to forest clearing and land-use since $3600 \mathrm{cal}$ BP in the western Swiss Alps. Journal of Paleolimnology 27 : 239-248.

Davies TRH, Smart CC, Turnbull JM. 2003. Water and sediment outbursts from advanced Franz Joseg glacier, New Zealand. Earth Surface Processes and Landforms 28 : 1081-1096. 
Enters D, Arnaud F, Poulenard J, Giguet-Covex C, Malet E, Wilhelm B. 2009. A Coupled Environmental Monitoring and Lake Sediment Study to Understand Factors Generating Torrential Floods in an Alpine Catchment (Giffre Valley, NW French Alps). Geophysical Research Abstracts 11, EGU2009-8837-1, EGU General Assembly, Vienna, Austria.

Fanetti D, Anselmetti FS, Chapron E, Sturm M, Vezzoli L. 2008. Megaturbidite deposits in the Holocene basin fill of Lake Como (Southern Alps, Italy). Palaeogeography,

Palaeoclimatology, Palaeoecology 259 : 323-340.

Gaume E, Bain V, Bernardara P, Newinger O, Barbuc M, Bateman A, Blaškovicová L, Blöschl G, Borga M, Dumitrescu A, Daliakopoulos I, Garcia J, Irimescu A, Kohnova S, Koutroulis A, Marchi L, Matreata S, Medina V, Preciso E, Sempere-Torres D, Stancalie G, Szolgay J, Tsanis I, Velasco D, Viglione A. 2009. A compilation of data on European flash floods. Journal of Hydrology 367 : 70-78.

Giguet-Covex C., Arnaud F, Poulenard J, Disnar JR, Delhon C, Francus P, David F, Enters D, Rey PJ, Delannoy JJ. 2011. Changes in erosion patterns during the Holocene in a currently treeless subalpine catchment inferred and from lake sediment geochemistry (Lake Anterne, $2063 \mathrm{~m}$ a.s.1., NW French Alps): The role of climate human activities. The Holocene 21(4) : 651-665.

Gilbert R, Crookshanks S, Hodder KR, Spagnol J, Stull RB. 2006. The record of an extreme flood in the sediments of montane Lillooet Lake, British Columbia: implications for paleoenvironmental assessment. Journal of Paleolimnology 35 : 737-745.

Gilli A, Anselmetti FS, Ariztegui D, McKenzie JA. 2003. A 600-year sedimentary record of flood events from two sub-alpine lakes (Schwendiseen, Northeastern Switzerland). Eclogae Geologica Helvetia 96(1) : 49-58.

Girardclos S, Schmidt OT, Sturm M, Ariztegui D, Pugin A, Anselmetti FS. 2007. The 1996 AD delta collapse and large turbidite in Lake Brienz. Marine Geology 241: 137-154.

Guyard H, Chapron E, St-Onge G, Anselmetti FS, Arnaud F, Magand O, Francus P, Melières MA. 2007. High-altitude varve records of abrupt environmental changes and mining activity 
over the last 4000 years in the Western French Alps (Lake Bramant, Grandes Rousses Massif). Quaternary Science Reviews 26 : 2644-2660.

Haeberli W. 1975. Untersuchungen zur Verbreitung von Parmafrost zwischen Flüelapass und Piz Grialetsch (Graubünden). Mitteilung der Versuchsanstalt für Wasserbau, Hydrologie und Glaziologie an der Eidgenössischen Technischen Hochschule Zürich 17, 221 p.

Hodder KR, Gilbert R, Desloges JR. 2007. Glaciolacustrine varved sediment as an alpine hydroclimatic proxy. Journal of Paleolimnology 38 : 365-394.

Holzhauser H, Magny M, Zumbühl HJ. 2005. Glacier and lake-level variations in west-central Europe over the last 3500 years. The Holocene 15 : 789-801.

IPCC, Kostaschuck RA, MacDonald GM. (Intergovernmental Panel on Climate Change), 2007. Climate change 2007-the physical science basis. Cambridge University Press: Cambridge.

Ivy-Ochs S, Kerschner H, Maisch M, Christl M, Kubik PW, Schlüchter C. 2009. Latest Pleistocene and Holocene glacier variations in the European Alps. Quaternary Science Reviews 28 : 2137-2149.

Kieffer-Weisse A and Bois P (2001) Estimation de paramètres statistiques des précipitations extrêmes dans les Alpes françaises. La Houille Blanche 1:62-70

Kuhn M, Markl G, Kaser G, Nickus U, Obleitner F, Schneider H. 1985. Fluctuations of climate and mass balance: different responses of two adjacent glaciers. Zeitschrift Gletscher und Glazialgeologie 21(2): 409-416

Lambert J, Levret-Albaret A. 1996. Mille ans de séismes en France. Ouest Editions, Nantes, 79 pp.

Larsen DJ, Miller GH, Geirsdóttir A, Ólafsdóttir S. 2012. Non-linear Holocene climate evolution in the North Atlantic: a high-resolution, multi-proxy record of glacier activity and 
environmental change from Hvítárvatn, central Iceland. Quaternary Science Reviews 39 : 14 25

Lignier V. 2001. Les sédiments lacustres et l'enregistrements de la paléosismicité, étude comparative de différents cas dans le Quaternaire des Alpes Nord-Occidentales et du TienShan Kyrghyze. Thèse de doctorat, Université de Savoie, 381 p.

Magny M. 2004. Holocene climate variability as reflected by mid-European lake-level fluctuations and its probable impact on prehistoric human settlements. Quaternary International $113: 65-79$.

Magny M, Peyron O, Gauthier E, Vannière B, Millet L, Vermot-Desroches V. 2011.

Quantitative estimates of temperature and precipitation changes over the last millennium from pollen and lake-level data at Lake Joux, Swiss Jura Mountains. Quaternary Research 75 : 4554.

Merz R, Blöschl G. 2003. Regional flood risk_what are the driving processes?

Water resources systems-hydrological risk, management and development (proceedings of symposium HS02b held during IUGG2003 at Sapporo). IAHS publications 281 : 49-58.

Millet L, Arnaud F, Heiri O, Magny, M, Verneaux V, Desmet M. 2009. Late-Holocene summer temperature reconstruction from chironomid assemblages of Lake Anterne, northern French Alps. The Holocene 19(2) : 317-328.

Monecke K, Anselmetti FS, Becker A, Sturm M, Giardini D. 2004. The record of historic earthquakes in lake sediments of Central Switzerlanc. Tectonophysics $394: 21-40$.

Moreno A, Valero-Garcés B, Gonzales-Sampériz P, Rico M. 2008. Flood response to rainfall variability during the last 2000 years inferred from the Taravilla Lake record (Central Iberian Range, Spain). Journal of Paleolimnology 40 : 943-961. 
Mulder T, Migeon S, Savoye B, Faugères JC. 2001. Inversely graded turibidite sequences in the deep Mediterranean: a record of deposits from flood-generated turbidity currents? GéoMarine Letters 21 : 86-93.

Mulder T, Chapron E. 2011. Flood deposits in continental and marine environments:

Character and significance. In Sediment transfer from shelf to deep water-Revisiting the delivery system, Slatt R M, Zavala C (eds). AAPG Studies in Geology 61 : 1-30.

Nesje A, Olaf Dahl S, Matthews JA, Berrisdorf MS. 2001. A 4500 years of river floods obtained from a sediment core in Lake Atnsjoen, eastern Norway. Journal of Paleolimnology 25 : 329-342.

Nussbaumer SU, Zumbühl H.J. 2012. The Little Ice Age history of the Glacier des Bossons (Mont Blanc massif, France): a new high-resolution glacier length curve based on historical documents. Climatic Change 111 : 301-334.

Parris AS, Bierman PR, Noren AJ, Prins MA, Lini A. 2010. Holocene paleostorms identified by particle size signatures in lake sediments from the northeastern United States. Journal of Paleolimnology 43(1) : 29-49.

Passega R. 1964. Grain-size representation by CM patterns as a geological tool. Journal of Sedimentary Petrology 34(4) : 830-847.

Radakovitch O, Charmasson S, Arnaud M, Bouisset P. 1999. 210Pb and Caesium Accumulation in the Rhône Delta Sediments. Estuarine, Coastal and Shelf Science 48 : 77 92.

Reimer PJ, Baillie MGL, Bard E, Bayliss A, Beck JW, Blackwell PG. 2009. IntCal09 and Marine09 radiocarbon age calibration curves, 0-50,000 years cal BP. Radiocarbon 51 : $1111-$ 1150.

Schär C, Frei C, Ltithi D, Davies HC. 1996. Surrogate climate-change scenarios for regional climate models. Geophysical Research Letters 23(6) : 669-672. 
Schnellmann M, Anselmetti FS, Giardinio D, Mc Kenzie JA. 2005. Mass movement-induced fold-and-thrust belt structures in unconsolidated sediments in Lake Lucerne (Switzerland). Sedimentology 52 : 271-289.

Seierstad J., Nesje A., Olaf Dahl S., Simonsen J.R., 2002. Holocene glacier fluctuations of Grovabreen and Holocene snow-avalanche activity reconstructed from lake sediments in Grningstlsvatnet, western Norway. The Holocene 12(2): 211-222

Shiki T, Kumon F, Inouchi Y, Kontani Y, Sakamoto T, Tateishi M, Matsubara H, Fukuyama K. 2000. Sedimentary features of the seismo-turbidites, Lake Biwa, Japan. Sedimentary Geology 135 : 37-50.

Stewart MM, Grosjean M, Kuglitsch FG, Nussbaumer SU, von Gunten L. 2011. Reconstructions of late Holocene paleofloods and glacier length changes in the Upper Engadine, Switzerland (ca. 1450 BC-AD 420). Palaeogeography, Palaeoclimatology, Palaeoecology 311 : 215-223.

Stoffel M, Lièvre I, Conus D, Grichting MA, Raetzo H, Gärtner HW, Monbaron M. 2005. 400 Years of Debris-Flow Activity and Triggering Weather Conditions: Ritigraben, Valais, Switzerland. Arctic, Antarctic, and Alpine Research 37(3) : 387-395.

Storen EN, Dahl SO, Nesje A, Paasche Ø. 2010. Identifying the sedimentary imprint of highfrequency Holocene river floods in lake sediments: development and application of a new method. Quaternary Science Reviews 29 : 3021-3033

Sturm M, Matter A. 1978. Turbidites and varves in Lake Brienz (Switzerland): deposition of clastic detritus by density currents. Special Publications of International Association of Sedimentologists 2 : 147-168.

Tachikawa K, Cartapanis O, Vidal L, Beaufort L, Barlyaeva T, Bard E. 2011. The precession phase of hydrological variability in the Western Pacific Warm Pool during the past $400 \mathrm{ka}$. Quaternary Science Review 30 : 3716-3727. 
Trenberth KE. 1999. Conceptual framework for changes of extremes of the hydrological cycle with climate change. Climatic Change 42 : 327-339.

Vasskog K, Nesje A, Støren EN, Waldmann N, Chapron E, Ariztegui D. 2011. A Holocene record of snow-avalanche and flood activity reconstructed from a lacustrine sedimentary sequence in Oldevatnet, western Norway. The Holocene 21(4) : 597-614.

Wilhelm B, Arnaud F, Enters D, Allignol F, Legaz A, Magand O, Revillon S, Giguet-Covex C, Malet E. 2012a. Does global warming favour the occurrence of extreme floods in European Alps? First evidences from a NW Alps proglacial lake sediment record. Climatic Change $113: 563-581$.

Wilhelm B, Arnaud F, Sabatier P, Crouzet C, Brisset E, Chaumillon E, Disnar JR, Guiter F, Malet E, Reyss JL, Tachikawa K, Bard E, Delannoy JJ. 2012b. 1400 years of extreme precipitation patterns over the Mediterranean French Alps and possible forcing mechanisms, Quaternary Research 78(1) : 1-12 
Table

\begin{tabular}{|c|c|c|c|c|c|c|c|}
\hline $\begin{array}{l}\text { Code } \\
\text { Lab }\end{array}$ & Core & $\begin{array}{l}\text { Core } \\
\text { depth } \\
(\mathrm{cm})\end{array}$ & $\begin{array}{c}\text { Cumulated } \\
\text { depth for core } \\
\text { BAR10II (cm) }\end{array}$ & $\begin{array}{c}\text { Composite } \\
\text { depth for core } \\
\text { BAR10II (cm) }\end{array}$ & Material & ${ }^{14} \mathrm{C}$ a BP & $\begin{array}{c}\text { cal. a } A D \\
( \pm 2 \text { sigmas })\end{array}$ \\
\hline $\begin{array}{c}\mathrm{SacA} \\
16864\end{array}$ & BAR09P1 & $74.5-75.5$ & $41-42$ & 14.3 & $\begin{array}{l}\text { Vegetal } \\
\text { remains }\end{array}$ & $165 \pm 30$ & $1662-1953$ \\
\hline $\begin{array}{l}\text { SacA } \\
16865\end{array}$ & BAR09P1 & $92.6-94$ & $46.5-47.5$ & 17.5 & $\begin{array}{l}\text { Vegetal } \\
\text { remains }\end{array}$ & $260 \pm 30$ & $1519-1951$ \\
\hline $\begin{array}{l}\text { SacA } \\
21322\end{array}$ & Bar10 I 04Ab & $82-83$ & $74.5-75.5$ & 31.8 & $\begin{array}{l}\text { Vegetal } \\
\text { remains }\end{array}$ & $945 \pm 30$ & $1024-1157$ \\
\hline $\begin{array}{l}\text { SacA } \\
21318\end{array}$ & Bar10 II 02A & $32-33$ & $76-77$ & 32.5 & $\begin{array}{l}\text { Vegetal } \\
\text { remains }\end{array}$ & $410 \pm 30$ & $1431-1620$ \\
\hline $\begin{array}{l}\text { SacA } \\
21321\end{array}$ & Bar10 I 02Ab & $58-59$ & $96.5-97.5$ & 48.6 & $\begin{array}{l}\text { Vegetal } \\
\text { remains }\end{array}$ & $470 \pm 30$ & $1410-1457$ \\
\hline $\begin{array}{c}\text { SacA } \\
21323\end{array}$ & Bar10 I 02Ab & $111-112$ & $139-140$ & 66 & $\begin{array}{l}\text { Vegetal } \\
\text { remains }\end{array}$ & $765 \pm 30$ & $1219-1282$ \\
\hline $\begin{array}{l}\text { SacA } \\
21324\end{array}$ & Bar10 I $02 \mathrm{Ab}$ & $111-112$ & $139-140$ & 66 & Bulk & $2035 \pm 30$ & $160 B C-50$ \\
\hline $\begin{array}{c}\text { SacA } \\
21319\end{array}$ & Bar10 I 04Bb & $62-63$ & $169-169$ & 77.8 & $\begin{array}{l}\text { Vegetal } \\
\text { remains }\end{array}$ & $1025 \pm 30$ & $900-1146$ \\
\hline $\begin{array}{c}\text { SacA } \\
21320\end{array}$ & Bar10 I 04Bb & $71-72$ & $176-177$ & 81.2 & $\begin{array}{l}\text { Vegetal } \\
\text { remains }\end{array}$ & $1295 \pm 30$ & $663-773$ \\
\hline
\end{tabular}

Table 1. Radiocarbon age list. All cumulated and composite depths are for core BAR10II and are based on the stratigraphic correlation shown figure 3. The composite depth was calculated by removing graded beds, which we interpret as instantaneous deposits. Samples in italics correspond to dates excluded when building the age-depth model. See text for explanation, nature of samples and calibration procedures.

Legends of figure 


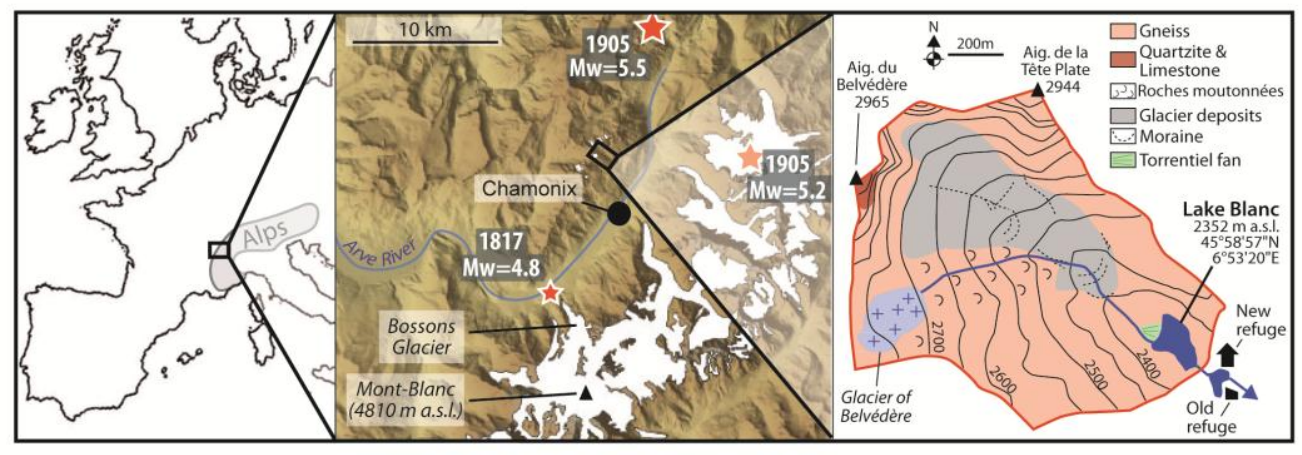

Fig. 1. Location of Lake Blanc in the northern French Alps, close to Chamonix in the MontBlanc region (left panel). Red stars show major historic earthquakes close to Chamonix and their respective magnitudes (Lambert and Levret-Albaret, 1996).Geological and geomorphological characteristics of the catchment area (right panel). 


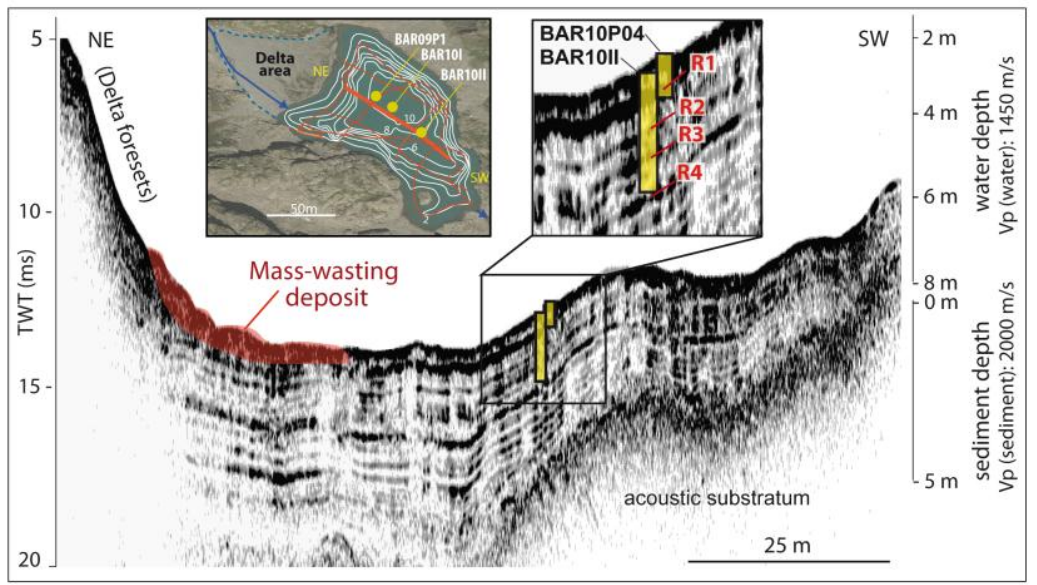

Fig. 2. Bathymetric map, coring sites, seismic grid and details of the NE-SW seismic profile. The seismic profile shows the positions of cores BAR10II and BAR10P04 and of the four upper high-amplitude reflections labeled R1 to R4, with increasing depth. 


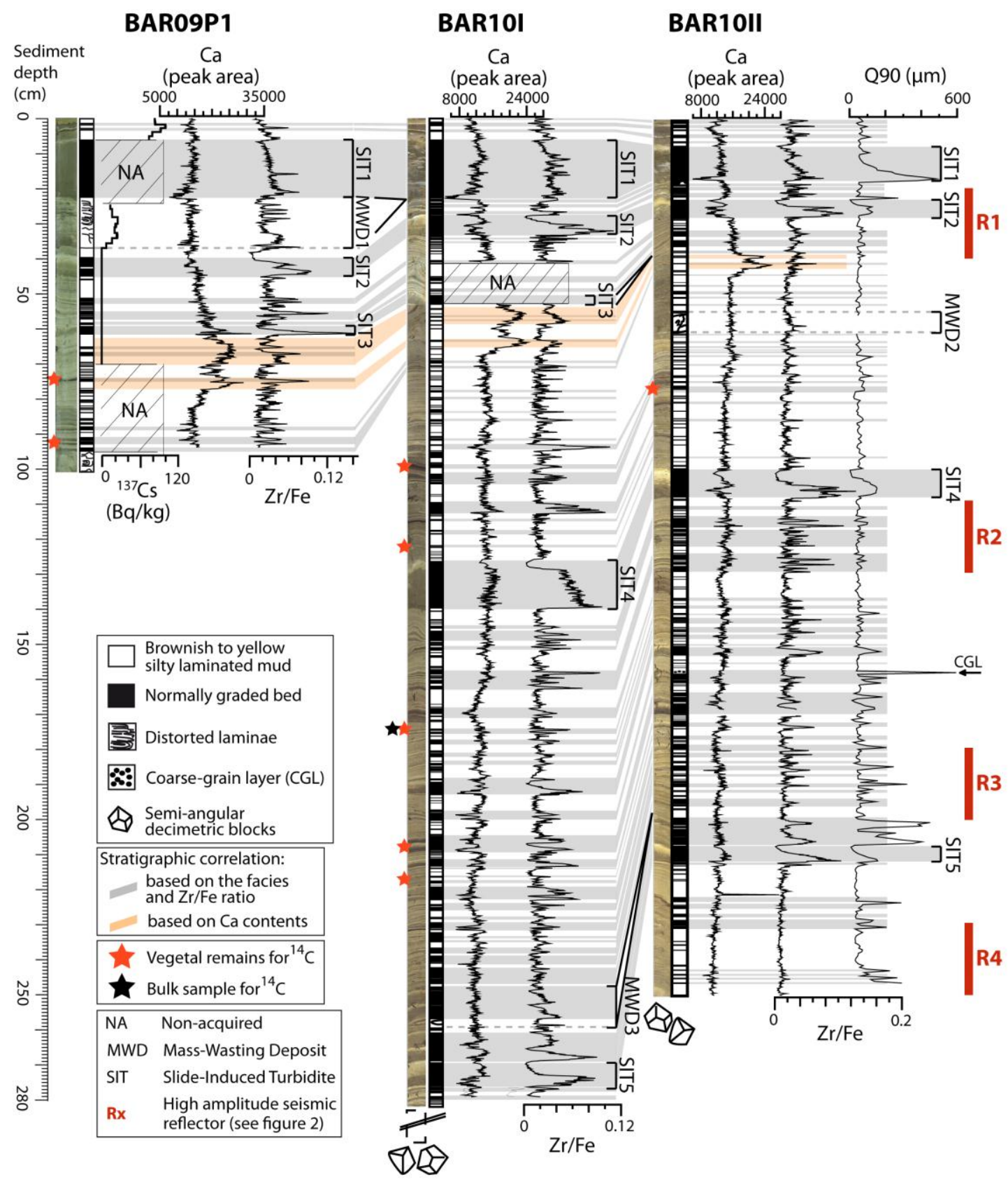

Fig. 3. Lithological descriptions of cores and stratigraphic correlation based on sedimentary facies, relative $\mathrm{Ca}$ contents and $\mathrm{Zr} / \mathrm{Fe}$ ratios. $\mathrm{Zr} / \mathrm{Fe}$ ratios, used as a high-resolution grain-size proxy, are shown beside the coarse percentile (Q90). The ${ }^{137}$ Cs profile for BAR09P1 is shown and available ${ }^{14} \mathrm{C}$ samples are indicated by red and black stars. Depths of the four upper highamplitude seismic reflections shown in figure 1 (R1 to R4) are given alongside core BAR10II. 


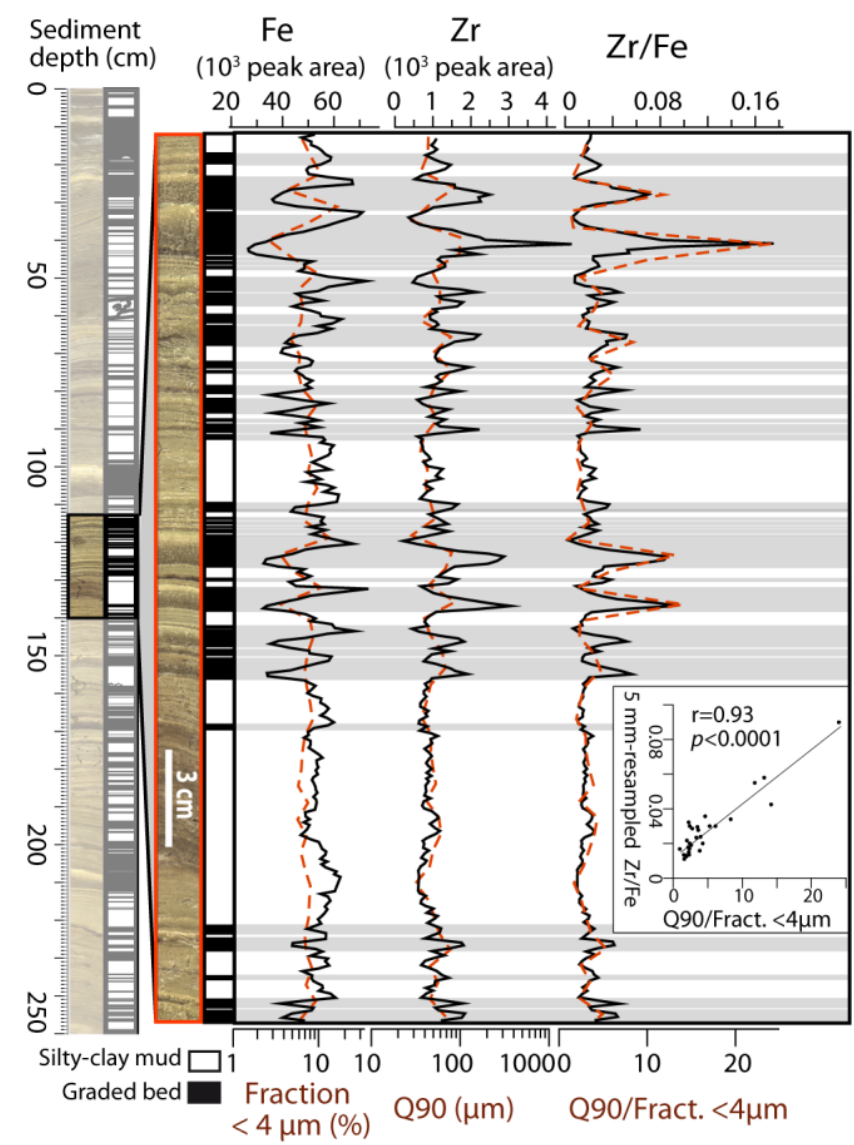

Fig. 4. High-resolution investigation of the relationship between geochemical ( $\mathrm{Fe}$ and $\mathrm{Zr}$ ) and grain size (fine fraction and Q90) variations. 


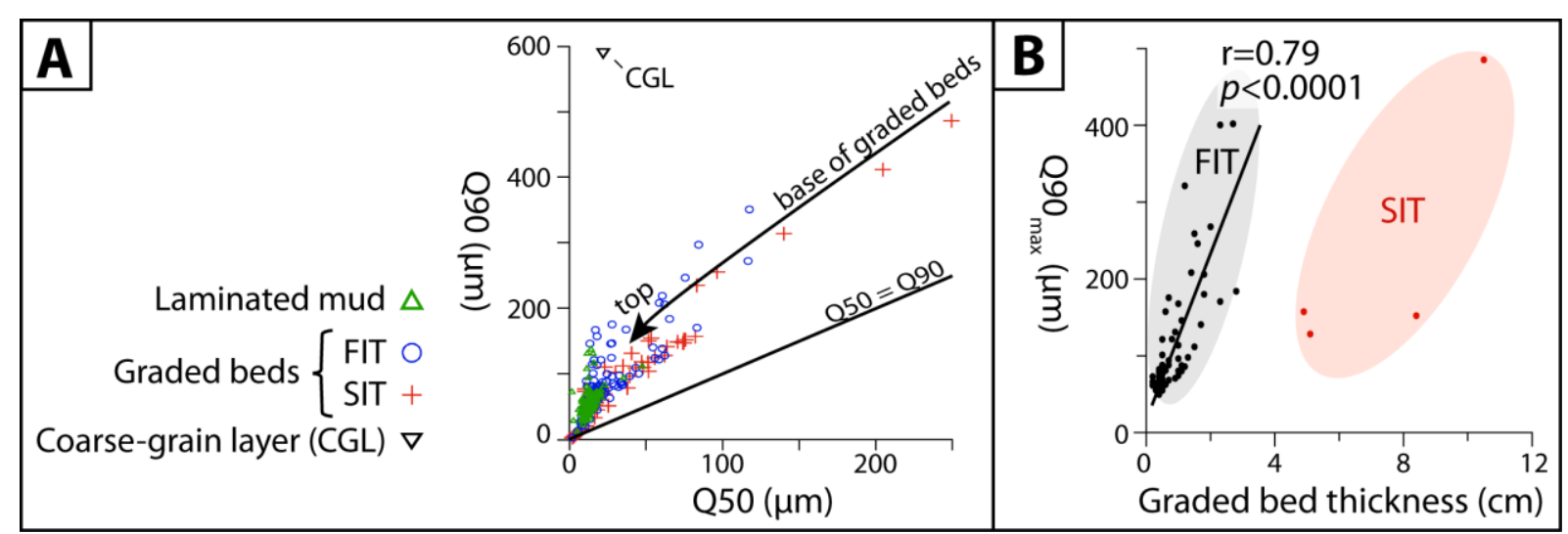

Fig. 5. Grain size characteristics of the different sedimentary facies of core BAR10II on a

Passega-type diagram (A) and of graded beds on a Q90max vs. deposit thickness plot (B). FIT

$=$ Flood-Induced Turbidite; SIT $=$ Slide-Induced Turbidite. 


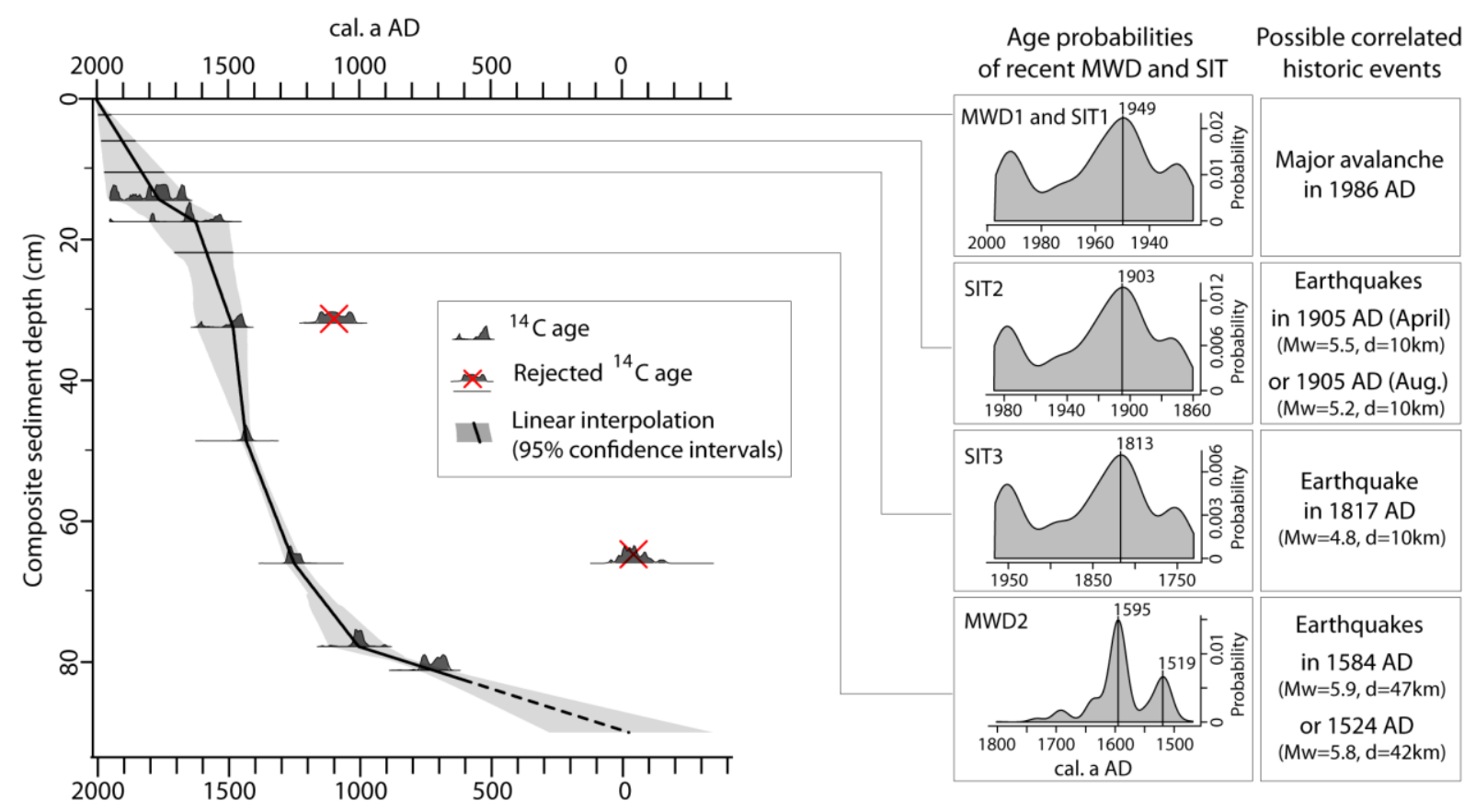

Fig. 6. Age-depth relationship for core BAR10II (left panel), age probabilities of the most recent MWD and SIT and possible correlated historic events (right panel). 


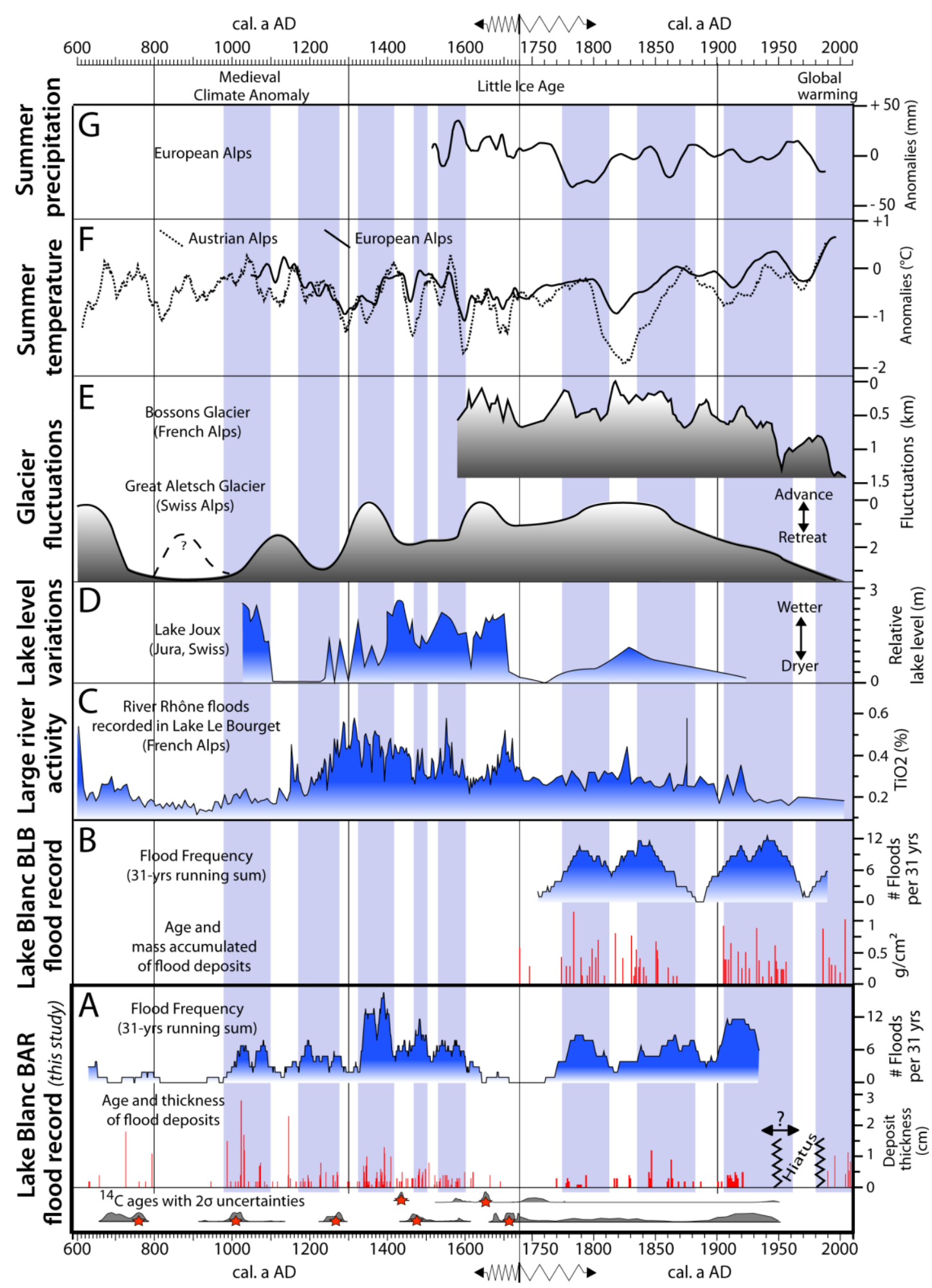

Fig. 7. Comparison of (A) the reconstructed Lake Blanc Aiguilles Rouges (BAR) flood record (this study) with (B) the Lake Blanc Belledonne (BLB) flood record (Wilhelm et al., 2012a), (C) the River Rhône flood record (Arnaud et al., 2012), (D) lake level variations for Lake Joux (Magny et al., 2011), (E) fluctuations of the Great Aletsch Glacier (Holzhauser et al., 2005) and Bossons Glacier (Nussbaumer and Zumbühl, 2012), (F) summer temperature reconstructions for the Austrian Alps, based on tree-rings (Büntgen et al., 2011), and for the 
European Alps, based on multiple proxies (Trachsel et al., 2012) and (G) summer precipitation reconstruction for the European Alps (Casty et al., 2005). Vertical blue bars indicate periods of high flood frequency, as revealed by the BAR record. Note that the time scale after $\mathrm{AD} 1740$ is stretched. Red stars in the lower panel show the ${ }^{14} \mathrm{C}$ ages used with their $2 \sigma$ uncertainty ranges. 